\title{
Oxide ion and proton conductivity in a family of highly oxygen deficient perovskite derivatives
}

Chloe A. Fuller ${ }^{\dagger}$, Douglas A. Blom ${ }^{\ddagger}$, Thomas Vogt ${ }^{\dagger \dagger}$, Ivana Radosavljevic Evans ${ }^{\dagger,}$, , and John S. O. Evans ${ }^{\dagger, *}$

† Department of Chemistry, Durham University, Science Site, South Road, Durham DH1 3LE, United Kingdom ‡ Department of Chemical Engineering and NanoCenter, University of South Carolina, Columbia, SC 29208, USA

${ }^{+\dagger}$ Department of Chemical Engineering, Chemistry and Biochemistry and NanoCenter, University of South Carolina, Columbia, SC 29208, USA

Table S1. Summary of the pellets used, and impedance measurements performed. Ticks in the atmospheres section indicate a dataset was collected under that atmosphere for that sample. Blue shows the data were collected on cooling and red on heating.

\begin{tabular}{|c|c|c|c|c|}
\hline Compound & Sintering Conditions / time / h @ & Density / \% & \multirow{2}{*}{\multicolumn{2}{|c|}{$\begin{array}{l}\text { Atmospheres } \\
\text { Air Dry } \mathrm{N}_{2}\end{array}$}} \\
\hline & temperature $/{ }^{\circ} \mathrm{C}$ & & & \\
\hline $\mathrm{Ba}_{3} \mathrm{YGa}_{2} \mathrm{O}_{7.5}$ & $24 @ 1200+8 @ 1400$ & 88 & $\checkmark \checkmark$ & $\checkmark \checkmark$ \\
\hline $\mathrm{Ba}_{2.95} \mathrm{La}_{0.05} \mathrm{YGa}_{2} \mathrm{O}_{7.525}$ & $24 @ 1200+8 @ 1400$ & 92 & $\checkmark$ & \\
\hline $\mathrm{Ba}_{2.90} \mathrm{La}_{0.10} \mathrm{YGa}_{2} \mathrm{O}_{7.55}$ & $24 @ 1200+8 @ 1400$ & 92 & $\checkmark$ & $\checkmark \checkmark$ \\
\hline $\mathrm{Ba}_{3} \mathrm{YGa}_{1.90} \mathrm{Zn}_{0.10} \mathrm{O}_{7.45}$ & $24 @ 1200+6 @ 1450$ & 83 & $\checkmark \checkmark$ & $\checkmark \checkmark$ \\
\hline $\mathrm{Ba}_{3} \mathrm{YGa}_{1.90} \mathrm{Ti}_{0.10} \mathrm{O}_{7.55}$ & $24 @ 1200+8 @ 1400$ & 91 & $\checkmark \checkmark$ & $\checkmark \checkmark$ \\
\hline $\mathrm{Ba}_{3} \mathrm{Y}_{0.95} \mathrm{Zr}_{0.05} \mathrm{Ga}_{2} \mathrm{O}_{7.52}$ & $24 @ 1200+8 @ 1400$ & 85 & $\checkmark \checkmark$ & $\checkmark \checkmark$ \\
\hline
\end{tabular}

Table S2. Crystallographic data for the room temperature structure of $\mathrm{Ba}_{3} \mathrm{YGa}_{2} \mathrm{O}_{7.5}$ with unit cell parameters $a=7.94820(5) \AA, b=$ $5.96986(4) \AA, c=18.4641(1) \AA$ and $B=91.2927(5)^{\circ}$ in space group $P 2 / c$.

\begin{tabular}{lllllll}
\hline Atom & Site & $\boldsymbol{x} / \boldsymbol{a}$ & $\boldsymbol{y} / \mathbf{b}$ & $\boldsymbol{z} / \boldsymbol{c}$ & Occ. & $\boldsymbol{B}_{\text {iso }} / \boldsymbol{A}^{2}$ \\
\hline Ba1 & $2 e$ & 0 & $0.2779(7)$ & 0.25 & 1 & $0.83(2)$ \\
$\mathrm{Ba} 2$ & $2 f$ & 0.5 & $0.3244(6)$ & 0.25 & 1 & $0.82(2)$ \\
$\mathrm{Ba} 3$ & $4 g$ & $0.0260(2)$ & $0.7502(6)$ & $0.0895(1)$ & 1 & $0.76(2)$ \\
$\mathrm{Ba} 4$ & $4 g$ & $0.4994(3)$ & $0.2470(6)$ & $0.5790(1)$ & 1 & $0.88(2)$ \\
$\mathrm{Y} 1$ & $4 g$ & $0.2468(2)$ & $0.2509(4)$ & $0.4100(1)$ & 1 & $0.72(2)$ \\
$\mathrm{Ga} 1$ & $4 g$ & $0.24467(19)$ & $0.2536(4)$ & $0.0582(1)$ & 1 & $0.69(2)$ \\
$\mathrm{Ga} 2$ & $4 g$ & $0.2283(2)$ & $0.7729(3)$ & $0.2662(1)$ & 1 & $0.66(2)$ \\
O1 & $2 e$ & 0 & $0.8010(7)$ & 0.25 & 1 & $1.50(6)$ \\
$\mathrm{O} 2$ & $4 g$ & $0.0494(3)$ & $0.7630(5)$ & $0.6095(1)$ & 1 & $1.15(3)$ \\
O3 & $4 g$ & $0.4666(3)$ & $0.2460(6)$ & $0.0913(1)$ & 1 & $1.14(3)$ \\
O4 & $4 g$ & $0.2761(3)$ & $0.0392(4)$ & $0.3103(1)$ & 1 & $1.04(4)$ \\
O5 & $4 g$ & $0.2459(4)$ & $0.5477(4)$ & $0.3360(2)$ & 1 & $0.94(3)$ \\
O6 & $4 g$ & $0.2338(4)$ & $0.4895(5)$ & $0.5021(1)$ & 1 & $0.99(4)$ \\
O7 & $4 g$ & $0.2309(4)$ & $0.0155(4)$ & $-0.0072(2)$ & 1 & $0.85(4)$ \\
O8 & $4 g$ & $0.3107(3)$ & $0.3298(4)$ & $0.6832(1)$ & 1 & $1.35(4)$ \\
\hline
\end{tabular}

Table S3. Bond lengths and angles in the room temperature model of $\mathrm{Ba}_{3} \mathrm{YGa}_{2} \mathrm{O}_{7.5}$.

\begin{tabular}{|c|c|c|c|c|c|c|c|c|c|}
\hline \multirow[t]{2}{*}{ Bond } & \multirow[t]{2}{*}{$\begin{array}{l}\text { Bond } \\
\text { length / A }\end{array}$} & \multirow[b]{2}{*}{$\mathrm{Ba} 1$} & \multicolumn{7}{|c|}{ Bond Angle $/^{\circ}$} \\
\hline & & & $\mathrm{O} 2$ & $\mathrm{O} 2$ & $\mathrm{O} 4$ & $\mathrm{O} 4$ & 01 & $\mathrm{O5}$ & $\mathrm{O5}$ \\
\hline $\mathrm{Ba} 1-\mathrm{O} 2$ & 2.6438 & $\mathrm{O} 2$ & & & & & & & \\
\hline $\mathrm{Ba} 1-\mathrm{O} 2$ & 2.6438 & $\mathrm{O} 2$ & 169.40 & & & & & & \\
\hline $\mathrm{Ba} 1-\mathrm{O} 4$ & 2.8242 & $\mathrm{O} 4$ & 72.41 & 102.06 & & & & & \\
\hline
\end{tabular}




\begin{tabular}{|c|c|c|c|c|c|c|c|c|c|c|c|}
\hline $\mathrm{Ba} 1-\mathrm{O} 4$ & 2.8242 & O4 & 119.39 & 102.06 & 72.41 & & & & & & \\
\hline $\mathrm{Ba} 1-\mathrm{O} 1$ & 2.8470 & 01 & 59.70 & 59.70 & 84.70 & 84.70 & & & & & \\
\hline $\mathrm{Ba} 1-\mathrm{O} 5$ & 2.9657 & O5 & 122.89 & 64.29 & 169.10 & 117.70 & 68.62 & & & & \\
\hline $\mathrm{Ba} 1-\mathrm{O} 5$ & 2.9657 & $\mathrm{O} 5$ & 114.21 & 122.89 & 169.10 & 64.29 & 68.62 & 117.70 & & & \\
\hline \multirow[t]{2}{*}{$\mathrm{Ba} 1-\mathrm{O} 1$} & 3.1228 & 01 & 57.11 & 57.11 & 180.00 & 120.30 & 120.30 & 95.30 & 95.30 & & \\
\hline & & $\mathrm{Ba} 2$ & $\mathrm{O} 4$ & $\mathrm{O} 4$ & 08 & O8 & O5 & $\mathrm{O} 5$ & $\mathrm{O} 3$ & & \\
\hline $\mathrm{Ba} 2-\mathrm{O} 4$ & 2.7194 & O4 & & & & & & & & & \\
\hline $\mathrm{Ba} 2-\mathrm{O} 4$ & 2.7194 & $\mathrm{O} 4$ & 102.47 & & & & & & & & \\
\hline $\mathrm{Ba} 2-\mathrm{O} 8$ & 2.8219 & O8 & 106.83 & 128.79 & & & & & & & \\
\hline $\mathrm{Ba} 2-\mathrm{O} 8$ & 2.8219 & 08 & 85.97 & 128.79 & 106.83 & & & & & & \\
\hline $\mathrm{Ba} 2-\mathrm{O} 5$ & 2.9193 & O5 & 78.28 & 62.30 & 66.17 & 167.37 & & & & & \\
\hline $\mathrm{Ba} 2-\mathrm{O} 5$ & 2.9193 & O5 & 125.66 & 62.30 & 78.28 & 167.37 & 66.17 & & & & \\
\hline $\mathrm{Ba} 2-\mathrm{O} 3$ & 2.9734 & O3 & 124.09 & 65.37 & 69.48 & 125.51 & 62.78 & 105.08 & & & \\
\hline \multirow[t]{2}{*}{$\mathrm{Ba} 2-\mathrm{O} 3$} & 2.9734 & $\mathrm{O} 3$ & 161.89 & 65.37 & 124.09 & 125.51 & 69.48 & 105.08 & 62.78 & & \\
\hline & & $\mathrm{Ba3}$ & 06 & O5 & 08 & 07 & $\mathrm{O} 7$ & $\mathrm{O} 2$ & 01 & 06 & \\
\hline Ba3-O6 & 2.7386 & 06 & & & & & & & & & \\
\hline $\mathrm{Ba} 3-\mathrm{O} 5$ & 2.8563 & O5 & 122.38 & & & & & & & & \\
\hline $\mathrm{Ba} 3-\mathrm{O} 8$ & 2.8575 & O8 & 103.60 & 77.85 & & & & & & & \\
\hline $\mathrm{Ba3}-\mathrm{O} 7$ & 2.8801 & 07 & 160.55 & 85.67 & 111.88 & & & & & & \\
\hline Ba3-O7 & 2.9120 & 07 & 79.16 & 90.91 & 164.84 & 64.52 & & & & & \\
\hline $\mathrm{Ba} 3-\mathrm{O} 2$ & 2.9349 & $\mathrm{O} 2$ & 60.26 & 68.14 & 92.42 & 113.89 & 123.66 & & & & \\
\hline $\mathrm{Ba} 3-\mathrm{O} 1$ & 2.9908 & 01 & 77.32 & 127.19 & 114.18 & 59.24 & 59.72 & 133.86 & & & \\
\hline $\mathrm{Ba} 3-\mathrm{O} 6$ & 3.0642 & 06 & 122.53 & 127.76 & 108.49 & 59.64 & 139.81 & 62.81 & 79.47 & & \\
\hline \multirow[t]{2}{*}{$\mathrm{Ba} 3-\mathrm{O} 2$} & 3.0910 & $\mathrm{O} 2$ & 66.45 & 89.28 & 164.36 & 125.41 & 125.76 & 73.58 & 64.35 & 61.12 & \\
\hline & & Ba4 & 08 & 05 & 07 & 06 & $\mathrm{O} 3$ & O3 & 06 & O7 & O3 \\
\hline $\mathrm{Ba} 4-\mathrm{O} 8$ & 2.5151 & 08 & & & & & & & & & \\
\hline Ba4-O5 & 2.8143 & $\mathrm{O} 5$ & 85.51 & & & & & & & & \\
\hline $\mathrm{Ba} 4-\mathrm{O} 7$ & 2.8967 & 07 & 86.13 & 154.70 & & & & & & & \\
\hline $\mathrm{Ba} 4-\mathrm{O} 6$ & 2.9040 & 06 & 123.46 & 124.15 & 80.60 & & & & & & \\
\hline $\mathrm{Ba} 4-\mathrm{O} 3$ & 2.9638 & O3 & 117.92 & 68.20 & 116.95 & 94.68 & & & & & \\
\hline $\mathrm{Ba} 4-\mathrm{O} 3$ & 3.0468 & $\mathrm{O} 3$ & 166.64 & 58.58 & 125.00 & 65.64 & 72.20 & & & & \\
\hline $\mathrm{Ba} 4-\mathrm{O} 6$ & 3.0589 & 06 & 65.61 & 127.69 & 90.49 & 59.53 & 63.33 & 134.86 & & & \\
\hline $\mathrm{Ba} 4-\mathrm{O} 7$ & 3.0643 & O7 & 119.41 & 119.14 & 58.03 & 60.72 & 91.85 & 174.97 & 94.45 & & \\
\hline $\mathrm{Ba} 4-\mathrm{O} 3$ & 3.1621 & $\mathrm{O} 3$ & 63.68 & 55.84 & 94.90 & 94.82 & 65.94 & 57.54 & 118.61 & 145.78 & \\
\hline \multirow[t]{2}{*}{$\mathrm{Ba} 4-\mathrm{O} 4$} & 3.1806 & $\mathrm{O} 4$ & 125.36 & 115.67 & 101.88 & 122.24 & 57.75 & 166.68 & 68.14 & 59.30 & 87.11 \\
\hline & & $\mathrm{Y} 1$ & O7 & O6 & $\mathrm{O} 5$ & $\mathrm{O} 4$ & $\mathrm{O} 3$ & & & & \\
\hline Y1-O7 & 2.2116 & 07 & & & & & & & & & \\
\hline Y1—O6 & 2.2225 & $\mathrm{O} 6$ & 85.85 & & & & & & & & \\
\hline Y1-O5 & 2.2374 & $\mathrm{O} 5$ & 87.72 & 172.83 & & & & & & & \\
\hline Y1-O4 & 2.2494 & $\mathrm{O} 4$ & 86.80 & 173.60 & 99.81 & & & & & & \\
\hline Y1-O3 & 2.2788 & $\mathrm{O} 3$ & 82.08 & 89.61 & 94.59 & 94.06 & & & & & \\
\hline \multirow[t]{2}{*}{$\mathrm{Y} 1-\mathrm{O} 2$} & 2.3750 & $\mathrm{O} 2$ & 170.28 & 88.68 & 86.88 & 94.32 & 90.45 & & & & \\
\hline & & Ga1 & $\mathrm{O} 2$ & 06 & $\mathrm{O} 3$ & & & & & & \\
\hline $\mathrm{Ga1-O}$ & 1.8391 & $\mathrm{O} 2$ & & & & & & & & & \\
\hline Ga1-O6 & 1.8516 & O6 & 107.67 & & & & & & & & \\
\hline Ga1-O3 & 1.8543 & $\mathrm{O} 3$ & 103.69 & 129.53 & & & & & & & \\
\hline
\end{tabular}




\begin{tabular}{ll|l|lll}
$\mathrm{Ga} 1-\mathrm{O} 7$ & 1.8667 & $\mathrm{O} 7$ & 103.65 & 105.52 & 104.73 \\
\hline & & $\mathrm{Ga} 2$ & $\mathrm{O} 8$ & $\mathrm{O} 4$ & $\mathrm{O} 1$ \\
\hline $\mathrm{Ga} 2-\mathrm{O} 8$ & 1.7885 & $\mathrm{O} 8$ & & & \\
$\mathrm{Ga} 2-\mathrm{O} 4$ & 1.8223 & $\mathrm{O} 4$ & 127.25 & & \\
$\mathrm{Ga} 2-\mathrm{O} 1$ & 1.8401 & $\mathrm{O} 1$ & 100.84 & 105.71 & \\
$\mathrm{Ga} 2-\mathrm{O} 5$ & 1.8654 & $\mathrm{O} 5$ & 103.67 & 107.96 & 108.77 \\
\hline
\end{tabular}

Table S4. Crystallographic data for the high-temperature structure of $\mathrm{Ba}_{3} \mathrm{YGa}_{2} \mathrm{O}_{7.5}$ with unit cell parameters $a=12.0602(1) \AA, b=$ 9.8282(2) $\AA, c=8.04982(6) \AA$ and $\gamma=107.844(3)^{\circ}$ at $1000{ }^{\circ} \mathrm{C}$ in space group $\mathrm{P} 112_{1} / \mathrm{a}$.

\begin{tabular}{lllllll}
\hline Atom & Site & $\boldsymbol{x} / \mathbf{a}$ & $\boldsymbol{y} / \boldsymbol{b}$ & $\boldsymbol{z} / \boldsymbol{c}$ & Occ. & $\boldsymbol{B}_{\text {iso }} / \mathbf{A}^{\mathbf{2}}$ \\
\hline Ba12-1 & $4 e$ & $0.2721(3)$ & $0.0036(5)$ & $0.0022(8)$ & 1 & $3.88(9)$ \\
Ba34-1 & $4 e$ & $0.0884(4)$ & $0.3323(4)$ & $0.4917(5)$ & 1 & $2.58(7)$ \\
Ba34-2 & $4 e$ & $0.0860(4)$ & $0.3266(4)$ & $0.0188(5)$ & 1 & $3.09(9)$ \\
Y1 & $4 e$ & $0.3342(6)$ & $0.3229(3)$ & $0.7464(6)$ & 1 & $1.74(5)$ \\
Ga1 & $4 e$ & $0.3418(5)$ & $0.3848(2)$ & $0.2528(6)$ & 1 & $1.76(5)$ \\
Ga2 & $4 e$ & $0.0041(6)$ & $0.0360(3)$ & $0.7802(4)$ & 1 & $1.66(7)$ \\
O1 & $2 a$ & 0 & 0 & 0 & 1 & $7.9(3)$ \\
O23-1 & $4 e$ & $0.3248(8)$ & $0.2985(7)$ & $0.4595(8)$ & 1 & $3.25(16)$ \\
O23-2 & $4 e$ & $0.3165(9)$ & $0.2986(8)$ & $0.0437(9)$ & 1 & $3.98(19)$ \\
O45-1 & $4 e$ & $0.1650(6)$ & $0.1385(6)$ & $0.7618(9)$ & 1 & $2.80(13)$ \\
O45-2 & $4 e$ & $0.4233(7)$ & $0.1684(7)$ & $0.7492(10)$ & 1 & $3.34(15)$ \\
O6 & $4 e$ & $0.5030(6)$ & $0.5002(7)$ & $0.2539(9)$ & 1 & $1.78(11)$ \\
O7 & $4 e$ & $0.2548(10)$ & $0.5087(9)$ & $0.2637(12)$ & 1 & $4.8(2)$ \\
O8 & $4 e$ & $0.0081(10)$ & $0.1303(9)$ & $0.3199(8)$ & 1 & $9.9(4)$ \\
\hline
\end{tabular}
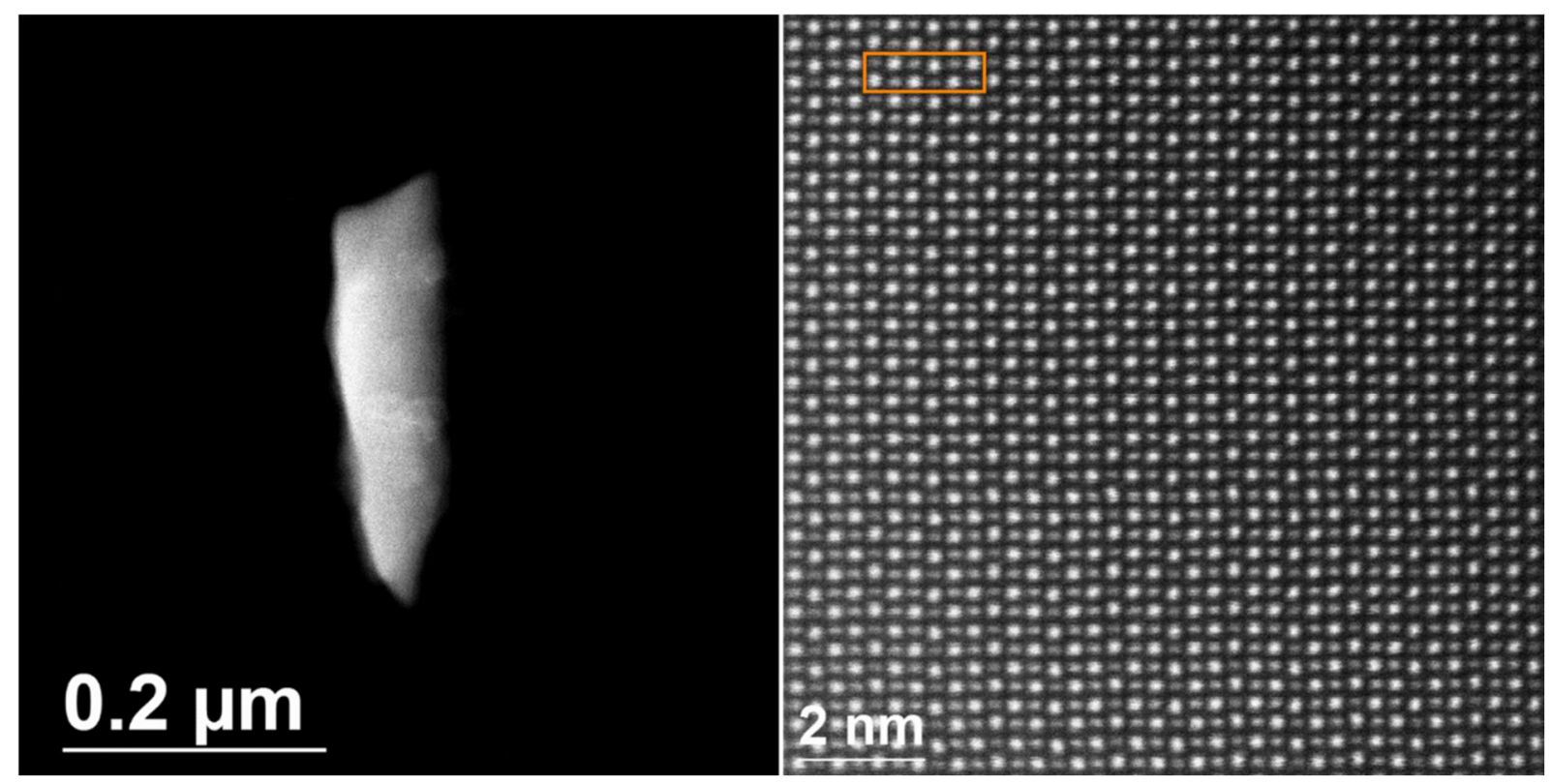

Figure S1. HAADF STEM images of a crystallite of $\mathrm{Ba}_{3} \mathrm{YGa}_{2} \mathrm{O}_{7.5}$ (left) and a magnified portion of it (right), containing approximately 106 unit cells. 

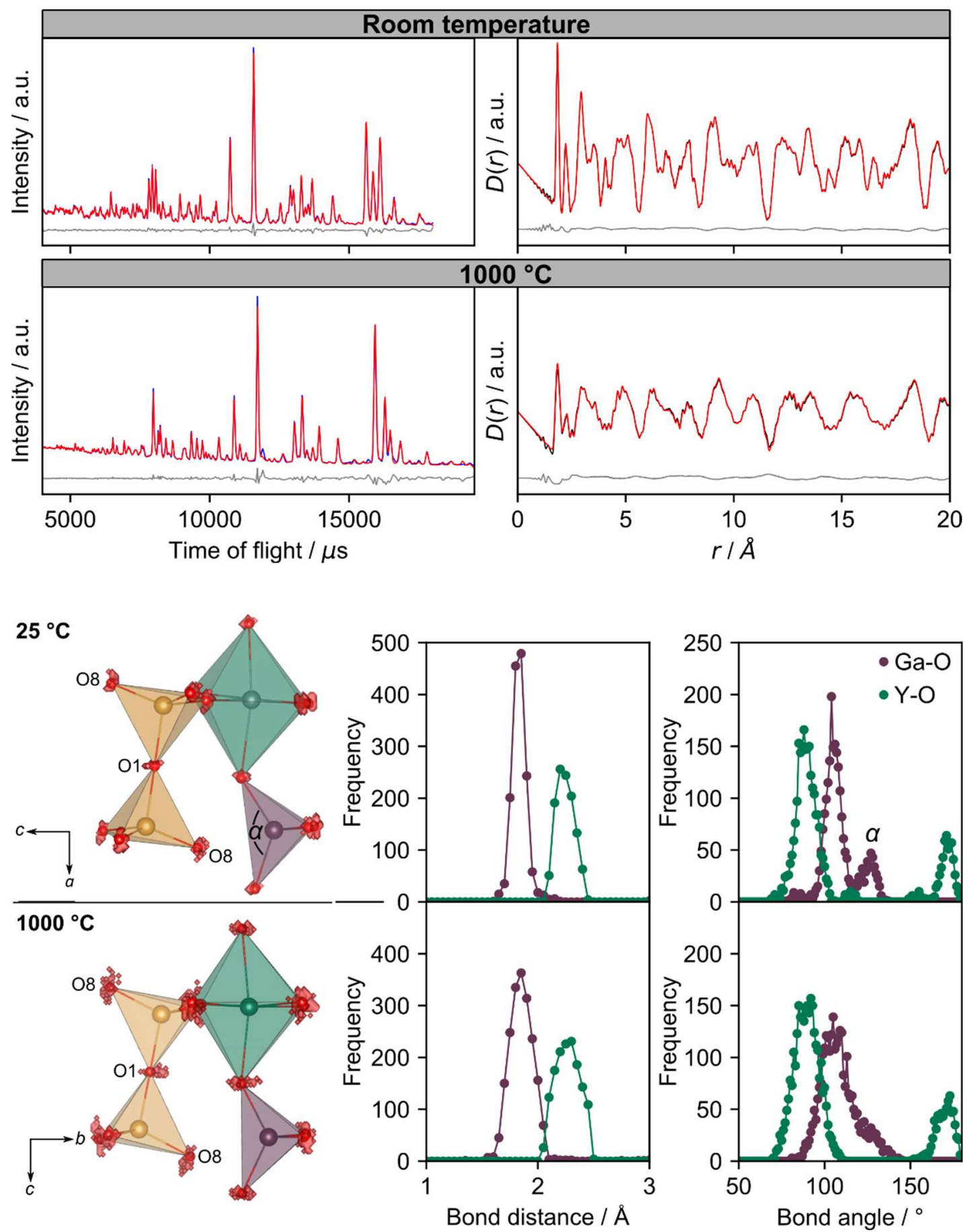

Figure S2. Upper panels show fits to the Bragg and PDF data for $\mathrm{Ba}_{3} \mathrm{YGa}_{2} \mathrm{O}_{7.5}$ at $25{ }^{\circ} \mathrm{C}\left(R_{\mathrm{wp}}=3.70 \%\right)$ and $1000{ }^{\circ} \mathrm{C}\left(R_{\mathrm{wp}}=3.32 \%\right)$. Lower panels show cloud plots illustrating the distribution of oxygen positions at $25^{\circ} \mathrm{C}$ and $1000{ }^{\circ} \mathrm{C}$ and the distribution of bond distances and angles within metal-centred polyhedral in each model. For $25^{\circ} \mathrm{C} P D F$ fitting, the monoclinic $P 2 / \mathrm{c}$ model derived from the joint $X$-ray and neutron refinement was used to create an approximately isotropic $4 \times 6 \times 2$ supercell containing 2592 atoms, and the model was refined simultaneously against the neutron Bragg and the PDF data, subject to local restraints to keep sensible geometries for coordination polyhedra. Oxygen cloud plots (shown in red in the lower left panels) were obtained by folding the PDF-fit supercell into a single average unit cell and are shown superimposed on the Rietveld-derived atomic positions. An equivalent procedure was followed for the $1000{ }^{\circ} \mathrm{C}$ data based on the Tamazyan model of Table S2. At both temperatures, the oxygen clouds are centred on the Rietveld-derived oxygen positions. The spread of positions required to fit the data rises at high temperature, consistent with increased thermal motion. The distribution of positions around $\mathrm{O} 1$ and $\mathrm{O} 8$ sites is consistent with slightly larger displacements of these oxygens, but we do not see the high level of disorder that would be associated with a $\mathrm{Cmcm}$ orthorhombic structure. 


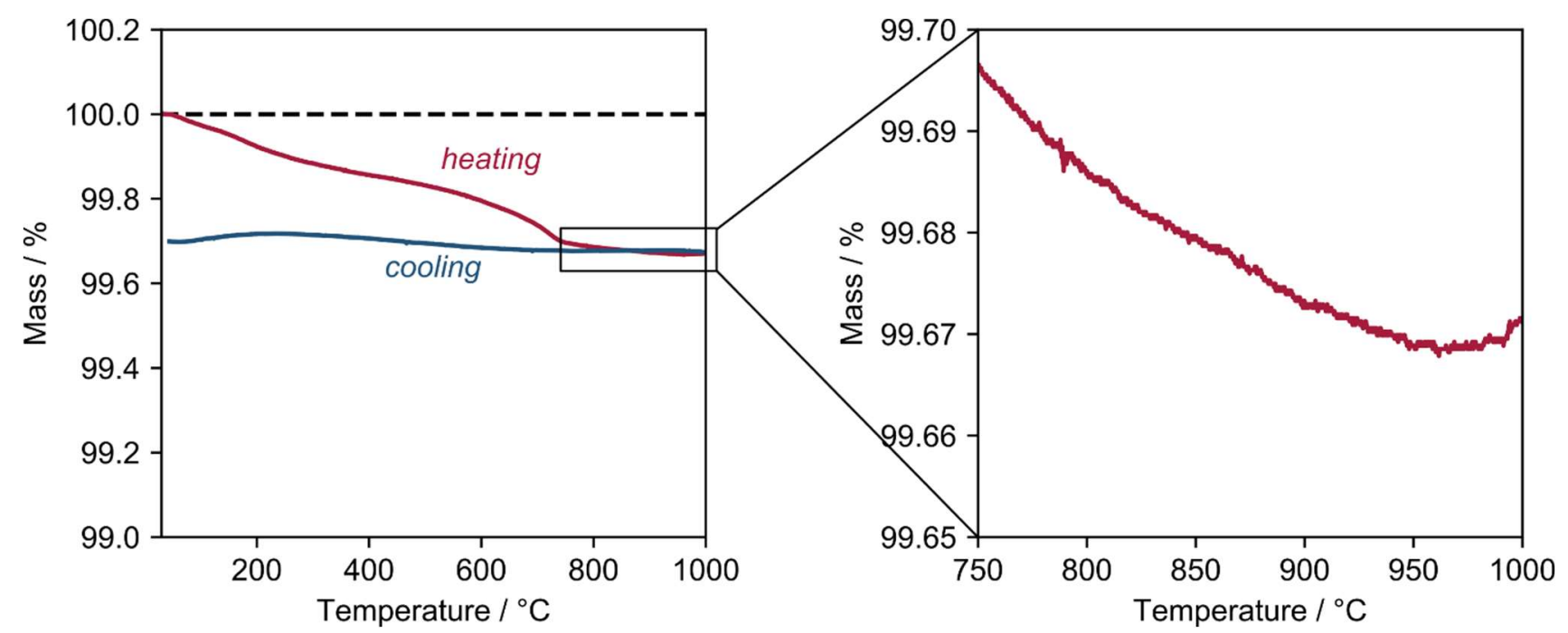

Figure S3. TGA trace of a sample of $\mathrm{Ba}_{3} \mathrm{YGa}_{2} \mathrm{O}_{7.5}$ in dry air following heating at $1150^{\circ} \mathrm{C}$ for $8.5 \mathrm{~h}$ and cooling to $150{ }^{\circ} \mathrm{C}$ at $5 \mathrm{~K} \mathrm{~min}^{-1}$.
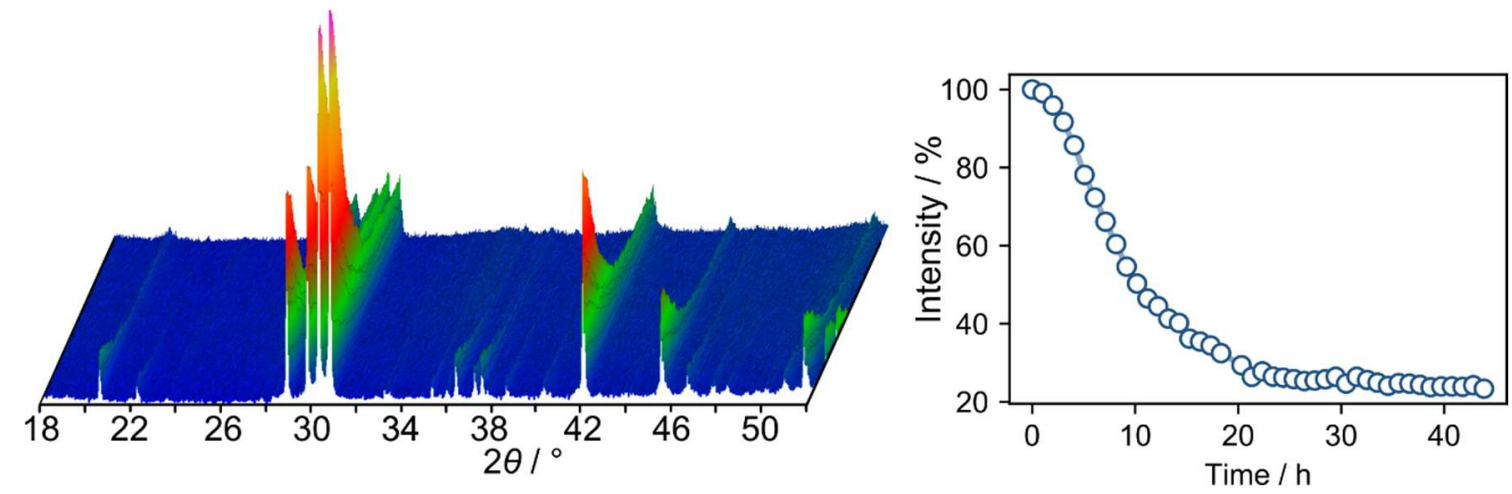

Figure S4. Diffraction patterns, left, and relative intensities of the main reflections, right, of dried $\mathrm{Ba}_{3} \mathrm{YGa}_{2} \mathrm{O}_{7.5}$ as a function of time. Each pattern was measured for $1 \mathrm{~h}$. 


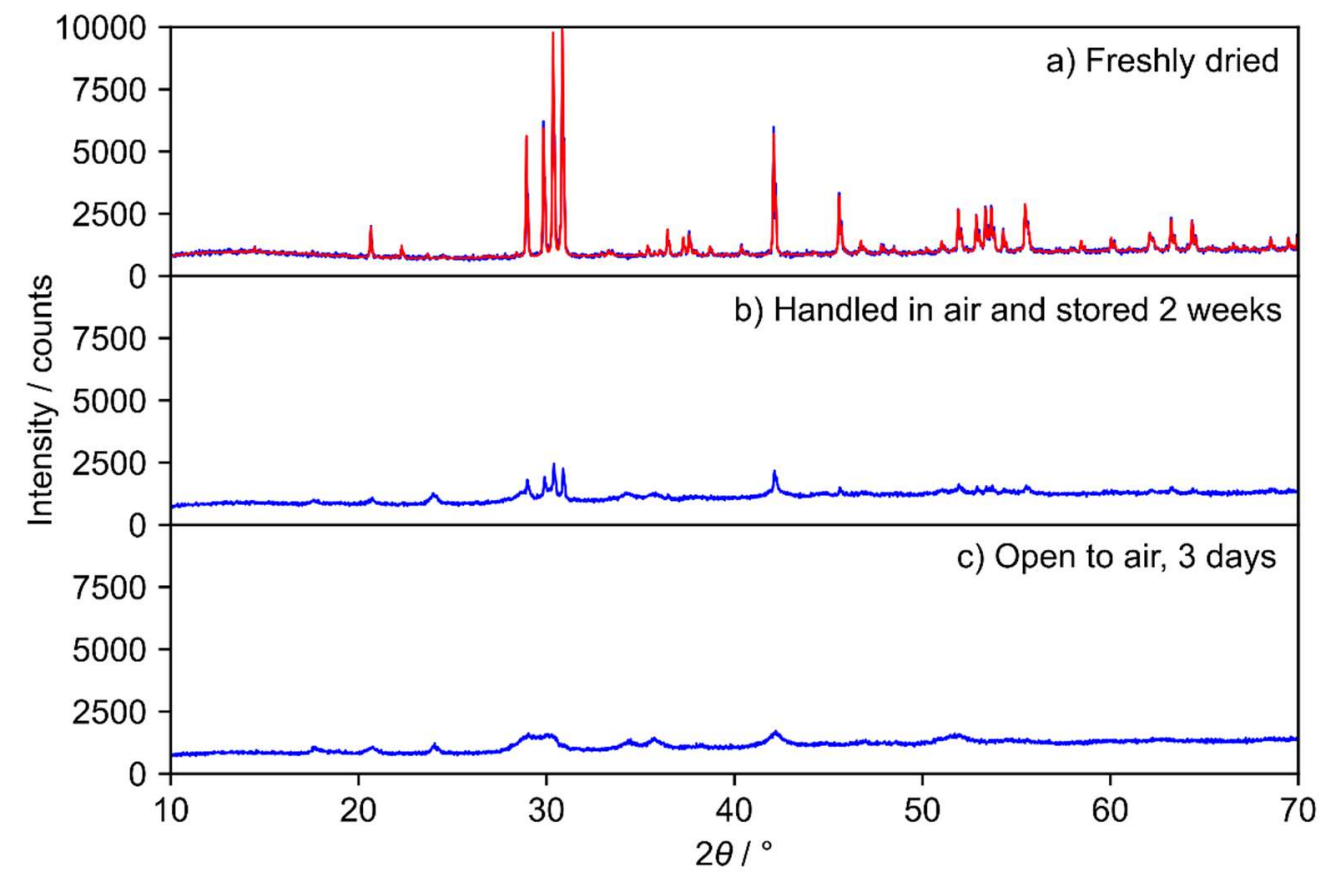

Figure S5. PXRD patterns of $\mathrm{Ba}_{3} \mathrm{YGa}_{2} \mathrm{O}_{7.5}$ samples with different thermal histories. The $\mathrm{y}$-scale is the same for all three panels to emphasise the differences. a) The freshly dried sample was heated at $1200{ }^{\circ} \mathrm{C}$ for $12 \mathrm{~h}$ and quench cooled. b) Sample slow cooled, handled in air and stored without special precautions for 2 weeks. c) Sample was stored in a glass vial with no lid. All three samples originated from the same batch. If samples such as that in c) are heated to $\sim 900{ }^{\circ} \mathrm{C}$ (Figure S8), rapid recrystallization occurs to give a diffraction pattern comparable to that in part a), with equally sharp peaks after heating to $1200^{\circ} \mathrm{C}$.

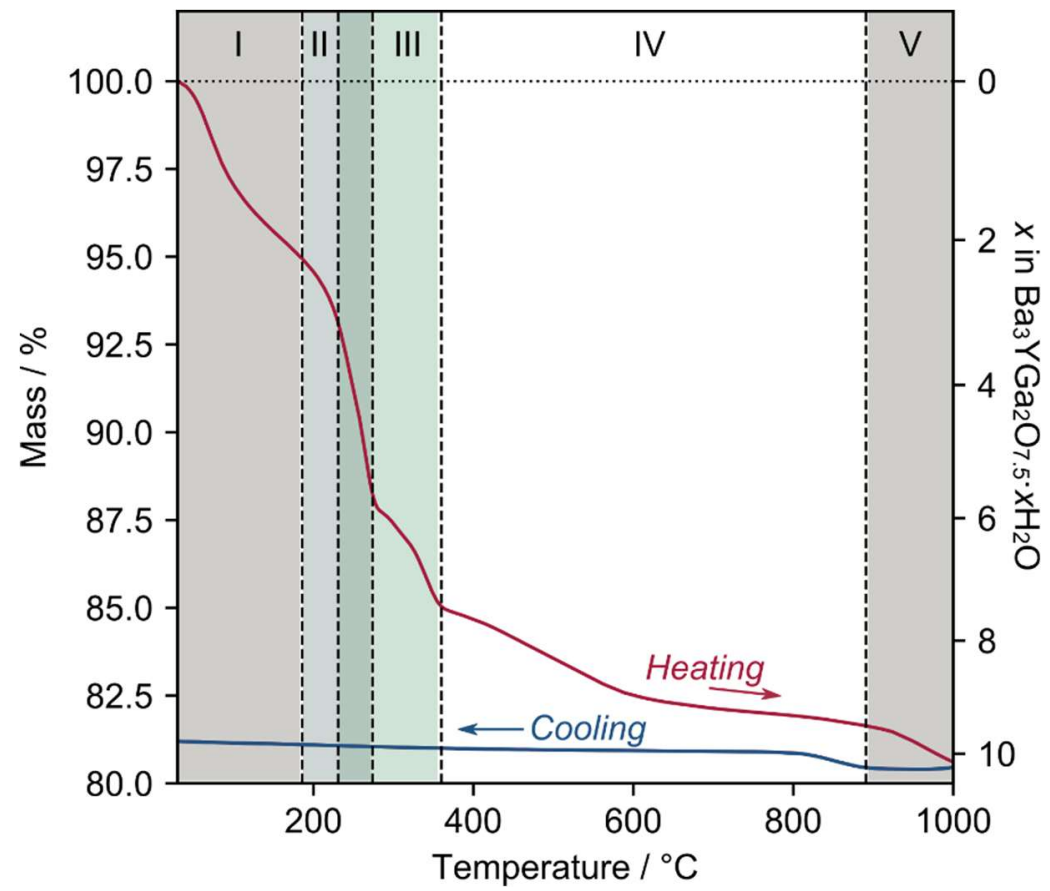

Figure S6. TGA trace of $\mathrm{Ba}_{3} \mathrm{YGa}_{2} \mathrm{O}_{7.5}$ after full hydration on heating and subsequent cooling in air. Dotted vertical lines indicate the temperatures at which transitions are observed in the corresponding PXRD experiment of Figure S8; shaded boxes and Roman numerals show which phase is present in each temperature region of Figure $S 8 . \mathrm{Ba}_{2.9} \mathrm{La}_{0.1} Y_{\mathrm{G}} \mathrm{a}_{2} \mathrm{O}_{7.55}$ and $\mathrm{Ba}_{3} Y G a_{1.9} \mathrm{Zn}_{0.1} \mathrm{O}_{7.45}$ showed similar behavior. 


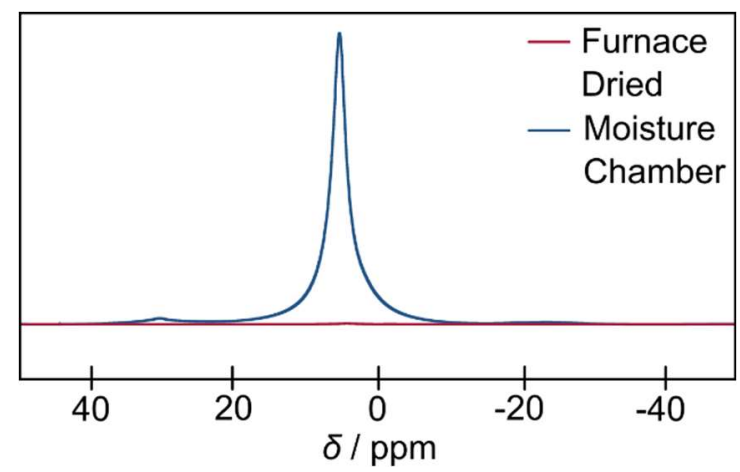

Figure S7. Proton NMR spectra of $\mathrm{Ba}_{3} \mathrm{YGa}_{2} \mathrm{O}_{7.5}$ immediately after heating at $1200{ }^{\circ} \mathrm{C}$, and after holding in a $74 \%$ moisture chamber for 1 week.

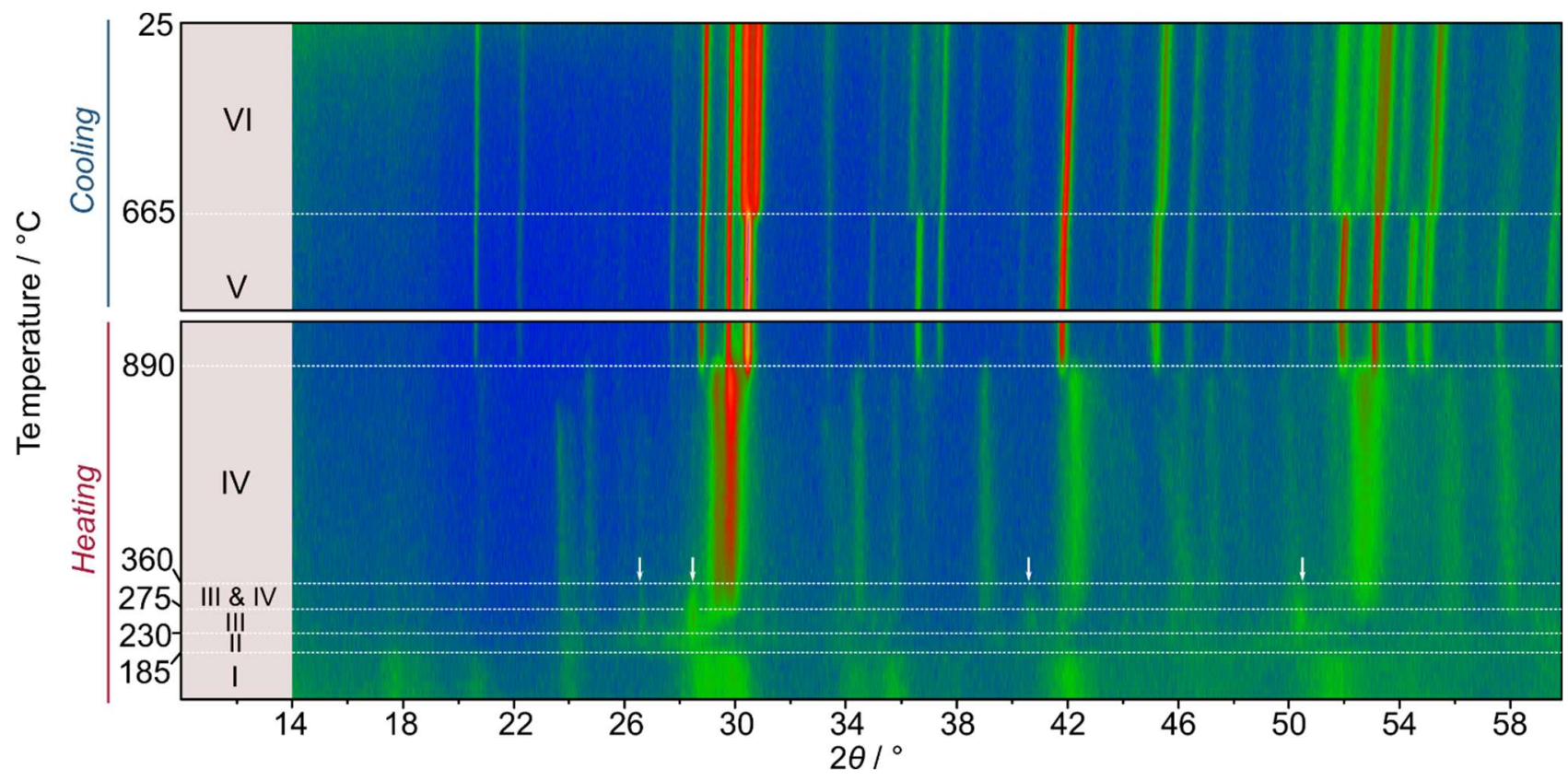

Figure S8. Evolution of the PXRD patterns of hydrated $\mathrm{Ba}_{3} \mathrm{YGa}_{2} \mathrm{O}_{7.5}$ on heating and cooling. The temperature scale for the heating panel has been expanded to show the low temperature region more clearly. Dashed lines indicate phase transitions, and the corresponding temperatures are marked. Roman numerals are used to denote the different intensity patterns in each region where each pattern likely corresponds to different set of phases. White arrows highlight the peaks belonging to pattern/phase III as this only exists over a small temperature range and is easily overlooked. 
$\mathrm{Ba}_{3} \mathrm{YGa}_{2} \mathrm{O}_{7.5} \mathrm{AIR}$
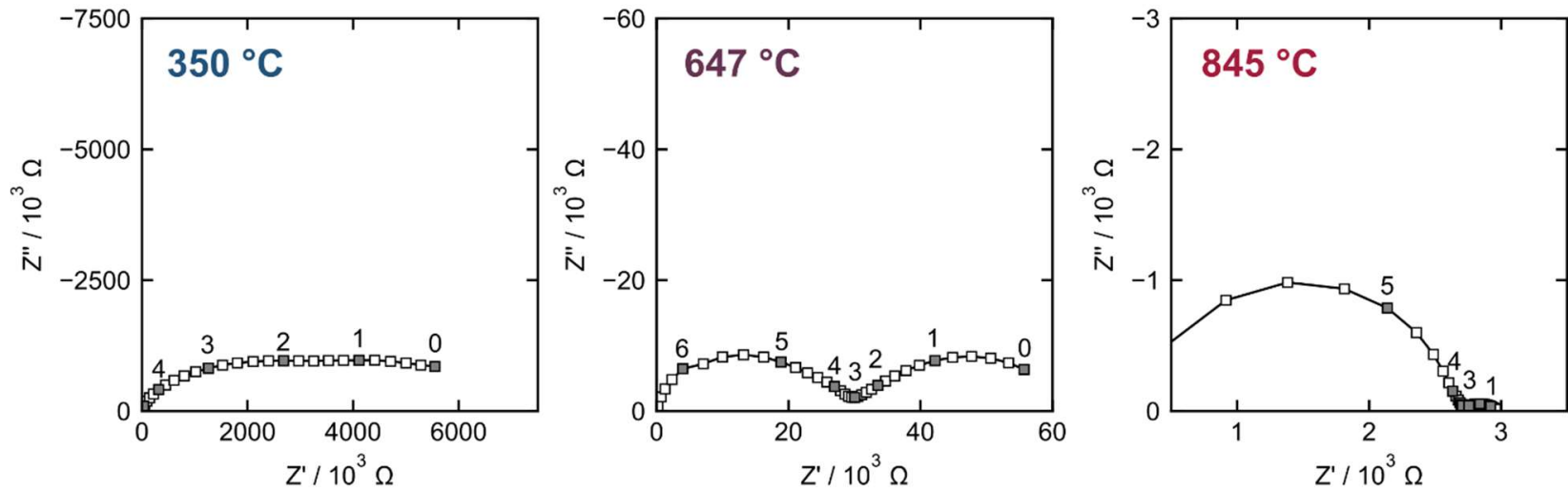

$\mathrm{Ba}_{2.9} \mathrm{La}_{0.1} \mathrm{YGa}_{2} \mathrm{O}_{7.5} \mathrm{AIR}$
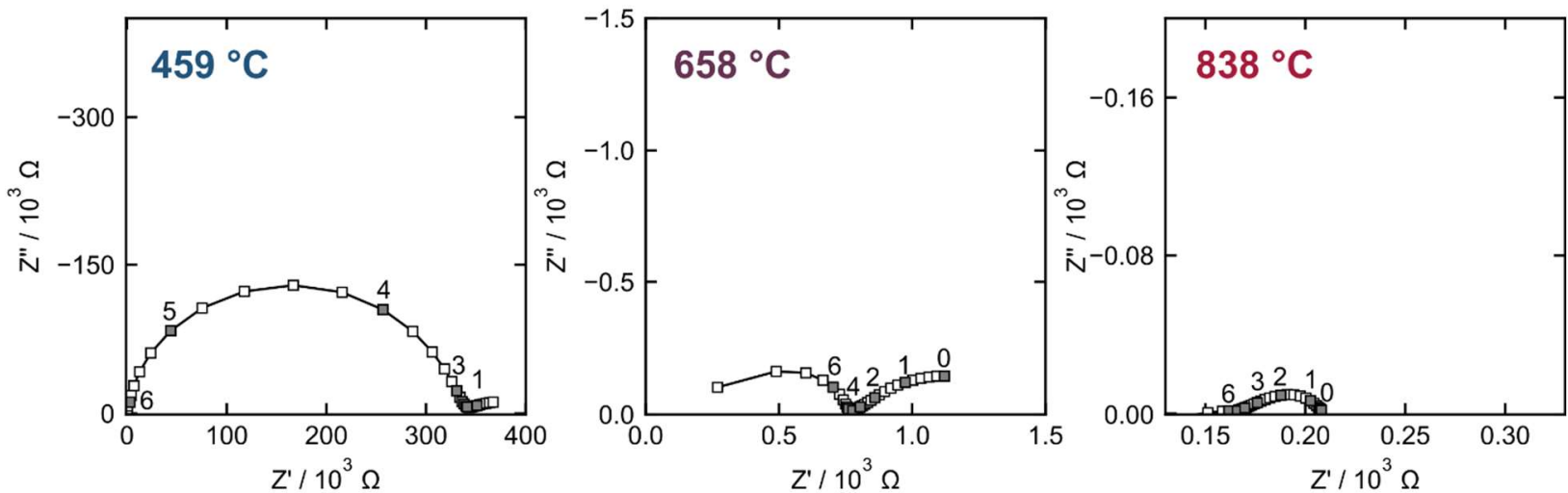

Ba2.9La0.1 YGa2 $\mathrm{O}_{7.5}$ DRY $\mathrm{N}_{2}$
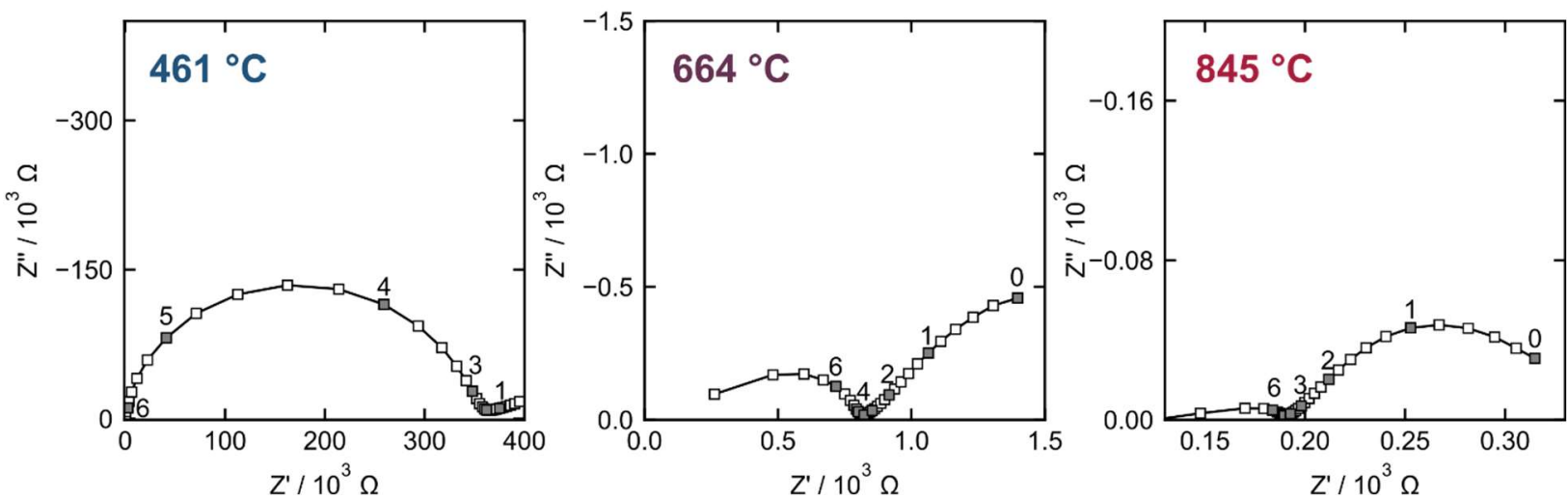

Figure S9. Example complex plane impedance spectra at low, mid and high temperature for $\mathrm{Ba}_{3} \mathrm{YGa}_{2} \mathrm{O}_{7.5}$ and $\mathrm{Ba}_{2.9} \mathrm{La}_{0.1} \mathrm{YGa}_{2} \mathrm{O}_{7.5}$. Filled grey squares mark specific frequencies, and the number above it shows the frequency logarithm. The shape of the complex impedance plots for both compounds change significantly with temperature, particularly at the phase transition. For $\mathrm{Ba}_{3} \mathrm{YGa}_{2} \mathrm{O}_{7.5}$, there is no obvious semi-circular signal at low temperatures, with the various sample responses overlapping to create a horizontal line. In $\mathrm{Ba}_{2.9} \mathrm{La}_{0.1} \mathrm{YGa}_{2} \mathrm{O}_{7.55}$, by $400{ }^{\circ} \mathrm{C}$ the expected semicircle has formed, corresponding to a capacitance of $\sim 10^{-12} \mathrm{~F} \mathrm{~cm}{ }^{-1}($ from $\omega R \mathrm{C}=1$ at the arc maximum) representing bulk transport. At intermediate temperatures, two distinct signals can be resolved for both compounds, and the capacitances of the high-and low-frequency semicircles were ${ }^{10^{-12}}$ and $10^{-6}-10^{-5} \mathrm{~F} \mathrm{~cm}^{-1}$, respectively, corresponding to bulk transport and a surface layer or electrode response. For $\mathrm{Ba}_{2.9} \mathrm{La}_{0.1} \mathrm{YGa}_{2} \mathrm{O}_{7.55}$, the low frequency response is characteristic of a Warburgtype electrode response, exemplified by the linear incline at approximately $45^{\circ}$, (particularly in the measurements under dry nitrogen). This behaviour is indicative of ionic conductivity with oxide ions able to diffuse into the electrode, and the prevalence of the Warburg response in $\mathrm{Ba}_{2.9} \mathrm{La}_{0.1} \mathrm{YGa}_{2} \mathrm{O}_{7.55}$ relative to $\mathrm{Ba}_{3} \mathrm{YGa}_{2} \mathrm{O}_{7.5}$ is consistent with the increase in conductivity. At high temperatures, both semicircles remain in $\mathrm{Ba}_{3} \mathrm{YGa}_{2} \mathrm{O}_{7.5}$ with the bulk signal becoming larger relative to the lower frequency signal. In contrast, the bulk signal in $\mathrm{Ba}_{2.9} \mathrm{La}_{0.1} \mathrm{YGa}_{2} \mathrm{O}_{7.55}$ is no longer present leaving only the signal from the electrode response which turns over to form a semicircle. The disappearance of the bulk semicircle is often seen in highly conductive samples at high temperatures when using this experimental setup, and the change in electrode behaviour indicates the ionic diffusion now occurs across the full thickness of the electrode. ${ }^{1}$ 


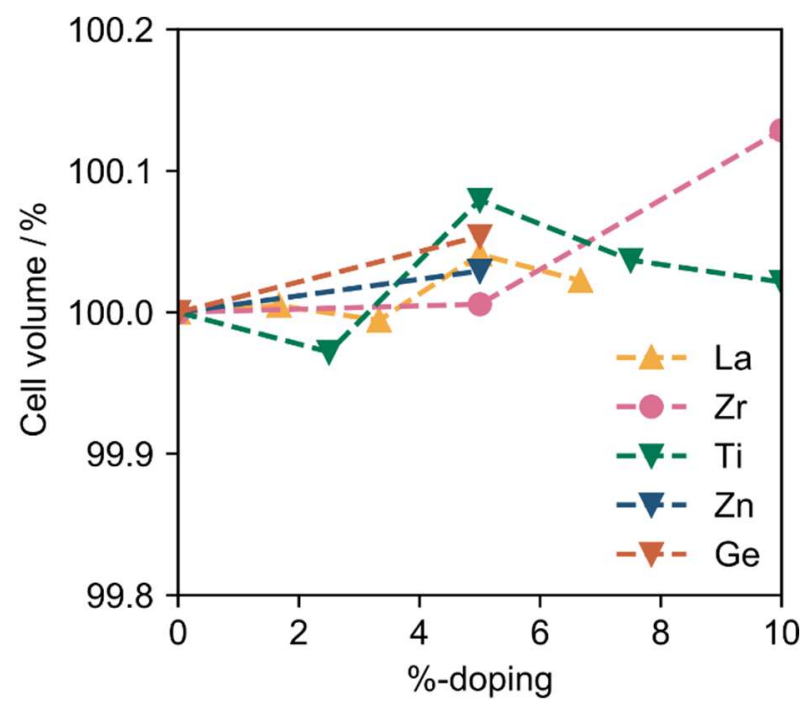

Figure S10. Cell volumes of substituted samples of $\mathrm{Ba}_{3} \mathrm{YGa}_{2} \mathrm{O}_{7.5}$. Upwards triangles, circles and downward triangles indicate substitution on the $A$, Oh and Td sites respectively. Substituent concentration is expressed as the percentage of atoms replaced on a particular site.
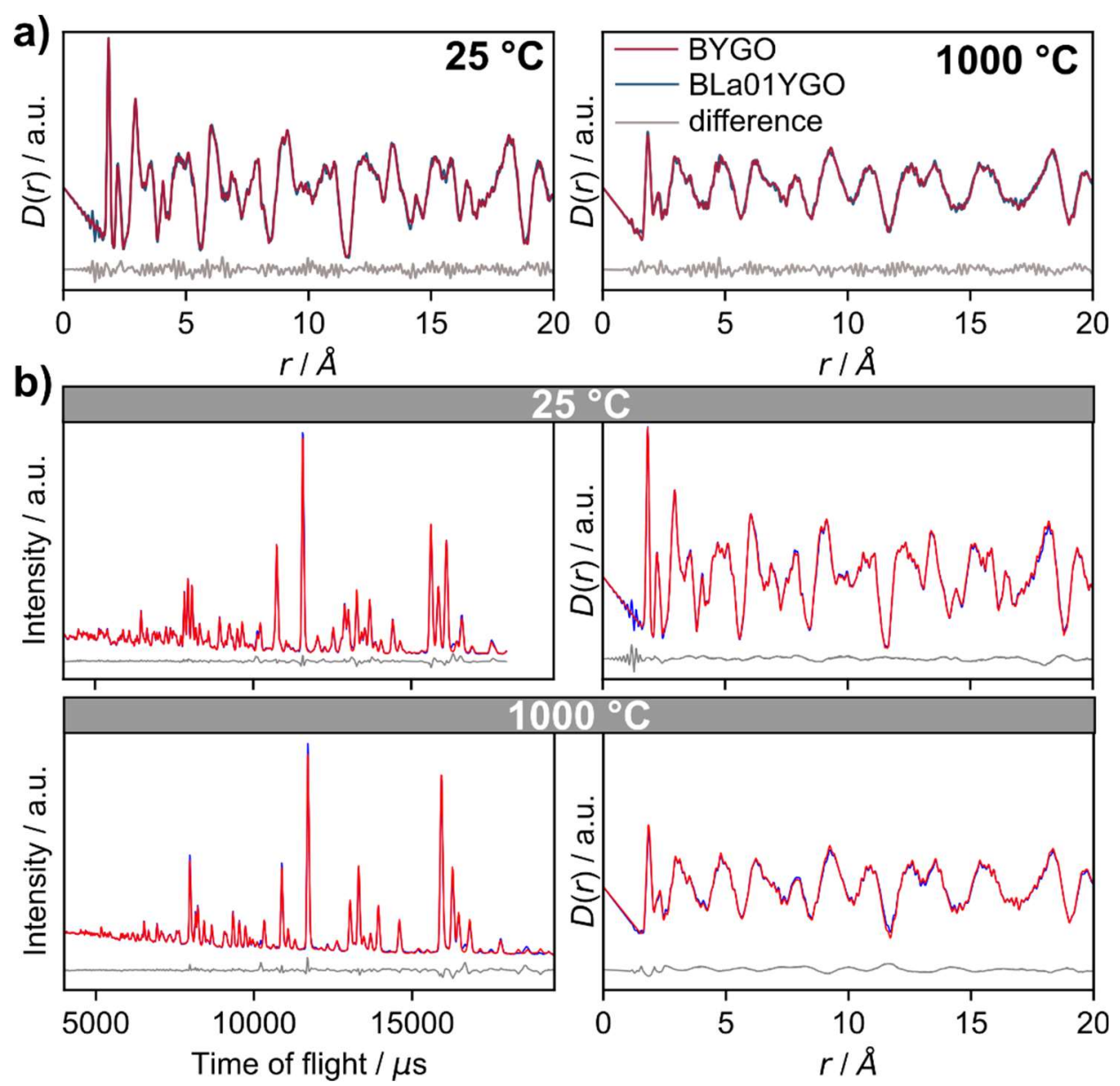

Figure S11. a) Superposition of the raw $\mathrm{D}(\mathrm{r})$ data for $\mathrm{Ba}_{3} \mathrm{YGa}_{2} \mathrm{O}_{7.5}$ and $\mathrm{Ba}_{2.9} \mathrm{La}_{0.1} \mathrm{YGa} \mathrm{O}_{7.55}$ measured on POLARIS at both $25^{\circ} \mathrm{C}$ and 1000 ${ }^{\circ} \mathrm{C}$; differences are minor at both temperatures. b) Fits of $\mathrm{P} 2 / \mathrm{C}\left(25^{\circ} \mathrm{C}\right)$ and Tamazyan models $\left(1000{ }^{\circ} \mathrm{C}\right)$ with added oxygen interstitials to the Bragg and PDF data of $\mathrm{Ba}_{2.9} \mathrm{La}_{0.1} \mathrm{YGa}_{2} \mathrm{O}_{7.55} . R_{\mathrm{wp}}\left(25^{\circ} \mathrm{C}\right)=3.34 \%, R_{\mathrm{wp}}\left(1000{ }^{\circ} \mathrm{C}\right)=2.23 \%$. 

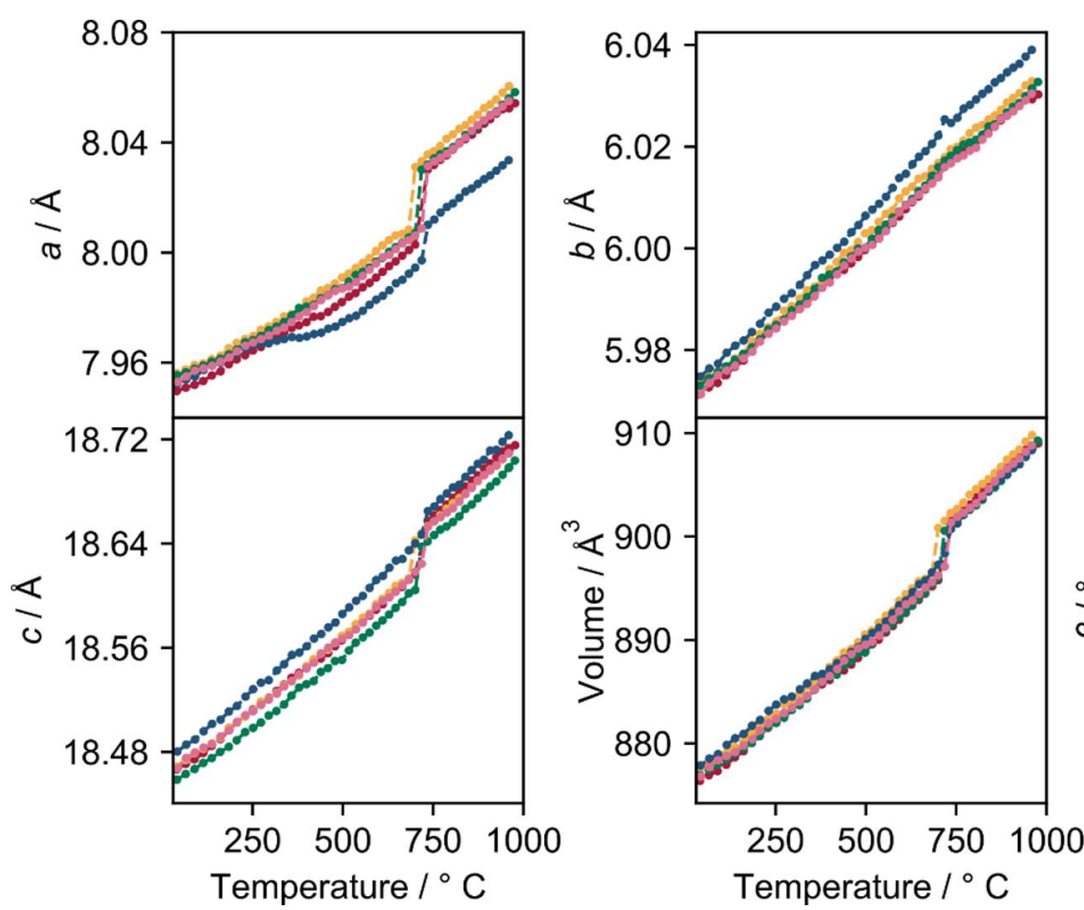
$\mathrm{Ba}_{3} \mathrm{YGa}_{2} \mathrm{O}_{7.5}$
$\mathrm{Ba}_{2.9} \mathrm{La}_{0.1} \mathrm{YGa}_{2} \mathrm{O}_{7.55}$
$\mathrm{Ba}_{3} \mathrm{YGa}_{1.9} \mathrm{Ti}_{0.1} \mathrm{O}_{7.55}$
$\mathrm{Ba}_{3} \mathrm{YGa}_{1.9} \mathrm{Zn}_{0.1} \mathrm{O}_{7.45}$
$\mathrm{Ba}_{3} \mathrm{Y}_{0.95} \mathrm{Zr}_{0.05} \mathrm{Ga}_{2} \mathrm{O}_{7.5}$

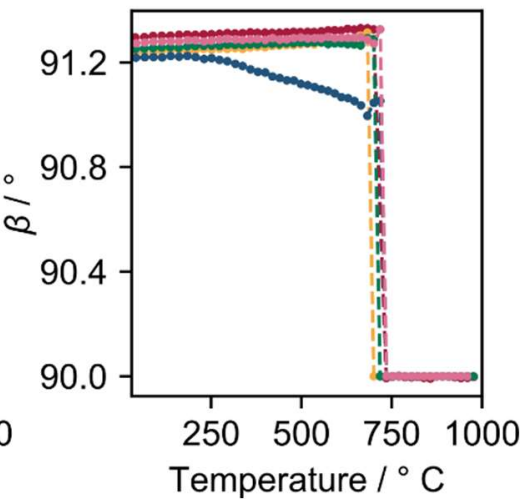

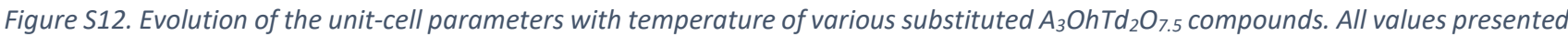
here are from cooling cycles but there were no significant differences between heating and cooling.

\section{References}

1. Irvine, J.T.S.; Sinclair, D.C.; West, A.R., Electroceramics: Characterization by Impedance Spectroscopy. Advanced Materials 1990, 2(3), 132 